\begin{tabular}{|l|l|l||}
\hline \multicolumn{2}{|c|}{ PublisherInfo } \\
\hline \hline PublisherName & $:$ & BioMed Central \\
\hline \hline PublisherLocation & $:$ & London \\
\hline \hline PublisherImprintName & $:$ & BioMed Central \\
\hline \hline
\end{tabular}

\title{
Fungus report stirs debate
}

\begin{tabular}{|l|c|l||}
\hline \multicolumn{2}{|c|}{ ArticleInfo } \\
\hline \hline ArticleID & $:$ & 5051 \\
\hline \hline ArticleDOI & $:$ & $10.1186 /$ gb-spotlight-20050117-01 \\
\hline \hline ArticleCitationID & $:$ & spotlight-20050117-01 \\
\hline \hline ArticleSequenceNumber & $:$ & 27 \\
\hline \hline ArticleCategory & $:$ & Research news \\
\hline ArticleFirstPage & $:$ & 1 \\
\hline \hline ArticleLastPage & $:$ & 3 \\
\hline \hline & & RegistrationDate : 2005-1-17 \\
\hline ArticleHistory & $:$ & OnlineDate \\
\hline \hline ArticleCopyright & $:$ & BioMed Central Ltd2005-1-17 \\
\hline \hline ArticleGrants & $:$ & \\
\hline \hline ArticleContext & $:$ & 130596611 \\
\hline \hline
\end{tabular}


Charles Q Choi

Email: cqchoi@nasw.org

An ancient group of fungi might possess more than one genome, Swiss researchers report in the January 13 issue of Nature.

Arbuscular mycorrhizal fungi colonize the roots of most land plants. Their cells contain hundreds of nuclei, leading Mohamed Hijri and Ian R. Sanders of the University of Lausanne in Switzerland to suggest multiple genomes could evolve within single individuals (Nature 2004, 433:160-3).

"These fungi have no sexual reproduction, which means if deleterious mutations accumulated, they might lead to extinction. But these fungi are extremely old, dated at 450 million years," Hijri said. "We think they developed this strategy of multiple genomes against deleterious mutations, such that some genes can get knocked out, but other genomes might have functional versions."

"This means Mendelian genetics and classical evolution cannot apply to these organisms. They are completely unique," Hijri told us.

The report has reignited a longstanding debate. "I think this data is not particularly believable. I'm a little worried they might have presented an experimental artifact or misinterpretation of results," said Teresa Pawlowska of Cornell University in Ithaca, NY, who did not participate in this study.

In 2001, Hijri and colleagues reported polymorphism of ribosomal DNA in spores of fungi as evidence for their idea. But in 2004, Pawlowska and John Taylor at the University of California at Berkeley suggested the variation was due to polyploidy. They focused on a POL1-like sequence (PLS1) in the arbuscular mycorrhizal fungus Glomus etunicatum, whose spores contain 13 variants of PLS1. Pawlowska and Taylor's mathematical model, based on the random inheritance of nuclei to each clonally produced offspring, predicted that if each variant existed in genetically different nuclei, then the loss of some variants would almost certainly occur after one generation. Instead, they found clonally produced spores possessed all 13 variants, suggesting polyploidy was behind the variation.

In the latest paper, Hijri and colleagues investigated the polyploidy question. Using flow cytometry, they measured the nuclear DNA content of G. etunicatum as 37.45 megabases (Mb). If G. etunicatum nuclei were $13 \mathrm{~N}$, the genome size of this fungus would be $2.88 \mathrm{Mb}$, much smaller than any other eukaryote and smaller than that of Escherichia coli and most other bacteria, the researchers argue.

Using real-time polymerase chain reaction, the investigators then estimated the number of copies of PLS1 was 1.88 per nucleus. Given a maximum of two copies per nucleus, Sanders and colleagues conclude the 13 variants must be spread out in different nuclei, meaning there is heterokaryosis, or genetic differences among the nuclei.

Pawlowska told us she disagrees with the new paper, citing her prior work, which, among other data, in the supplementary section noted that two isolates of the fungi from different locations, "one from Minnesota and the other from California, had both a complement of 13 variants of a genetic marker. According to their argument, if you expect all the nuclei to be different, you would expect to find different numbers of variants in different isolates due to loss and acquisition of different types of nuclei." 
Soren Rosendahl of the University of Copenhagen, who did not participate in either study, said both opposing groups did excellent work. "It's clear they are using different methods," he told us. In his team's investigation of arbuscular mycorrhizal fungi G. mosseae, G. geosporum, and G. caledonium, which analyzed genetic variations based on expressed DNA instead of genomic DNA as Hijri and colleagues did, "we never saw this heterokaryosis. But then again, we used a different method and different organisms, so that doesn't resolve the problem."

Pawlowska plans on repeating Hijri and colleagues' experiment in her own lab soon. "The fact this paper is published makes the whole question more visible and hopefully will draw more researchers to apply different methods and tools to address this problem," she said.

\section{References}

1. Nature, [http://www.nature.com]

2. Mohamed Hijri, [http://www.unil.ch/dee/page7251_fr.html]

3. Teresa Pawlowska, [http://ppathw3.cals.cornell.edu/People/labs/Pawlowska/Index.html]

4. Evidence for the evolution of multiple genomes in arbuscular mycorrhizal fungi

5. Organization of genetic variation in individuals of arbuscular mycorrhizal fungi

6. Soren Rosendahl, [http://www.bi.ku.dk/staff/staff-vip-details.asp?ID=33]

7. Development and amplification of multiple co-dominant genetic markers from single spores of arbuscular mycorrhizal fungi by nested multiplex PCR 